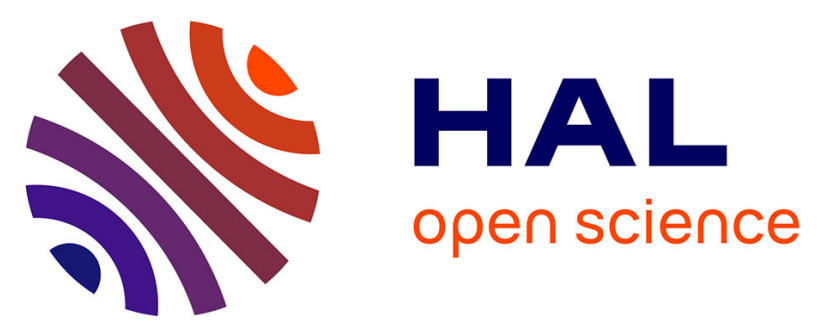

\title{
Sources of dissolved organic carbon in small volcanic mountainous tropical rivers, examples from Guadeloupe (French West Indies)
}

Emily Lloret, Céline Dessert, Heather L. Buss, Carine Chaduteau, Sylvain Huon, Patrick Albéric, Marc F. Benedetti

\section{To cite this version:}

Emily Lloret, Céline Dessert, Heather L. Buss, Carine Chaduteau, Sylvain Huon, et al.. Sources of dissolved organic carbon in small volcanic mountainous tropical rivers, examples from Guadeloupe (French West Indies). Geoderma, 2016, 282, pp.129-138. 10.1016/j.geoderma.2016.07.014 . insu01352450

\author{
HAL Id: insu-01352450 \\ https://hal-insu.archives-ouvertes.fr/insu-01352450
}

Submitted on 24 Jan 2017

HAL is a multi-disciplinary open access archive for the deposit and dissemination of scientific research documents, whether they are published or not. The documents may come from teaching and research institutions in France or abroad, or from public or private research centers.
L'archive ouverte pluridisciplinaire HAL, est destinée au dépôt et à la diffusion de documents scientifiques de niveau recherche, publiés ou non, émanant des établissements d'enseignement et de recherche français ou étrangers, des laboratoires publics ou privés.

\section{(1) (1) $\$$}

Distributed under a Creative Commons Attribution - NonCommercial - NoDerivatives| 4.0 


\title{
Sources of dissolved organic carbon in small volcanic mountainous tropical rivers, examples from Guadeloupe (French West Indies)
}

\author{
Emily Lloret, Céline Dessert, Heather L. Buss, Carine Chaduteau, Sylvain Huon, Patrick \\ Alberic, Marc F. Benedetti
}

\begin{abstract}
In the tropical zone, small watersheds are affected by intense meteorological events. These events play an important role in the erosion of soils and therefore on the sources of organic carbon in small tropical rivers. We studied the geochemistry of two soils on Basse-Terre Island (French West Indies, FWI): ferralitic soil and Andosol. The two studied soils are very similar in terms of soil organic matter (SOM) and soil solution parameters. The total organic carbon (TOC) and total nitrogen (TN) contents vary between 1.7 and $92 \mathrm{~g} \mathrm{~kg}^{-1}$ and between 0.1 and $5.5 \mathrm{~g} \mathrm{~kg}^{-1}$, respectively, with the highest concentrations observed in the topsoil. The $\mathrm{C} / \mathrm{N}$ ratios are relatively constant throughout the soil profiles (ca. 12). The carbon isotopic composition of SOM varies between $-27.3 \%$ and $-22.7 \%$ and presents an enrichment with increasing depth of soil profiles. Dissolved organic carbon (DOC) concentrations in soil solutions, varying from 3.2 to $91.3 \mathrm{mg} \mathrm{L}^{-1}$, are similar for the both extraction used in lab (with milliQ water and $\left.\mathrm{Ca}\left(\mathrm{NO}_{3}\right)_{2}\right)$ but are higher than those measured in soil solutions sampled from lysimeters $(0.65-1.46 \mathrm{mg}$ $\left.\mathrm{L}^{-1}\right)$. The isotopic compositions of DOC obtained by extractions and SOM are comparable, with $\delta^{13} \mathrm{C}$ values ranging from $-28.6 \%$ to $-25.8 \%$. The DOC sampled from lysimeters is systematically depleted in ${ }^{13} \mathrm{C}$ compared to DOC obtained by extractions, with $\delta^{13} \mathrm{C}$ values of $-33.8 \%$ o to $-30.6 \%$. The enrichment of $\delta^{13} \mathrm{C}$ of SOM through the soil profiles is either consistent with the carbon isotopic fractionation of SOM by decomposing organisms, or the differential mineralization of both labile and stable carbon stocks in soils. DOC concentrations in stream waters vary between 0.46 and $5.75 \mathrm{mg} \mathrm{L}^{-1}$, and are generally lower during low water level than floods. The isotopic compositions of DOC in the rivers range from $-38.9 \%$ to $-27.2 \%$, with $\delta^{13} \mathrm{C}$ values, which are more depleted in ${ }^{13} \mathrm{C}$ during low water level than flood events. The $\delta^{13} \mathrm{C}_{\mathrm{DOC}}$ of water river samples and soil solutions obtained by extraction and collected with lysimeters demonstrates that the DOC in rivers derives essentially from both the lixiviation of the soil surface layers during floods and groundwater flow during low water levels. Lixiviation of soil surface layers can be boosted by significant increases of intensity and duration of meteorological events and can strongly favor the release of surface soil organic matter in rivers and the impoverishment in nutrients of soil surface layers.
\end{abstract}

Keywords : Organic carbon sources; SOM; Soil solution; DOC; Small tropical rivers

\section{Introduction}

Rivers represent the major export of carbon from continents to oceans, with a global carbon flux (dissolved and particulate, organic and inorganic carbon) of 400-900 $\mathrm{Mt} \mathrm{yr}^{-1}$ (Hedges, J.I., et al., 1997, Schlünz, B. and Schneider, R.R., 2000 and Aitkenhead-Peterson, J.A., et al., 2003). The organic contribution (dissolved and particulate) represents about $40 \%$ of the global continental carbon flux (Hedges, J.I., et al., 1997, Schlünz, B. and Schneider, R.R., 2000 and Aitkenhead-Peterson, J.A., et al., 2003). Locally, the contribution of organic carbon could be higher than that of inorganic carbon. This is notably observed for large tropical river systems (Huang et al., 2012), which have particular hydrological processes (Wohl et al., 2012), for which the dissolved form can represent more than $60 \%$ of the total organic carbon export (Schlesinger, W.H. and Melack, J.M., 1981, Hope, D., et al., 1994, Ludwig, W., et al., 1996a and Ludwig, W 
1996a, 1996b). For small rivers directly connected to ocean basins with limited floodplains and mangroves, particulate organic carbon (POC) export is usually higher than dissolved organic carbon (DOC) export (Alvarez-Cobelas et al., 2012). Moreover, in mountainous tropical islands (e.g., Taiwan, New Zealand, Guadeloupe), the majority part of the organic carbon export occurs during flood events (Hilton et al., 2008a; Fujii et al., 2009; Bass et al., 2011; Lloret et al., 2013). Accordingly, the sources of organic carbon exported from the catchments vary with the hydrological stage, in particular for small rivers which can sustained by quick or ground flow (Lloret et al., 2011).

The major sources of organic carbon in rivers are either autochthonous (DOC is directly produced in the river by biological activity) or allochthonous (detrital inputs) (e.g., Aitkenhead-Peterson et al., 2003; Mulholland, 2003; Finlay and Kendall, 2007). In the case of allochthonous sources, the main input is due to soil erosion. During erosive rainfall events, organic carbon contained in soil organic matter (SOM) can be intensively either leached or eroded and transferred to aquatic ecosystems in dissolved and particulate forms, respectively (Lal, 2004). During low water stages, DOC input to rivers can also be completed by soil water infiltration. With $1400-1500 \mathrm{Gt}$ of carbon, the SOM pool is one of the major carbon surface reservoirs (Schlesinger, 1977; Gregory et al., 1999) and stores twice the quantity of carbon contained in the vegetation. Accordingly, changes in SOM abundance and composition have important effects on the global carbon cycle as well as on soil ecosystems.

The organic matter amounts in soils are essentially regulated by the biological production and the decay rates of organic compounds. Plant residues (litter) falling onto soil surface are gradually decomposed through physical fragmentation, faunal and micro-faunal interactions (decomposers), mineralization, and humus formation (Baudin et al., 2007). The overall processes induce variations in the concentration and in the isotopic composition of total organic carbon (TOC) through the soil profile. The decomposition of litter and SOM induces a differential decrease of carbon and nitrogen contents in soils. As they are not recycled at the same rate, the $\mathrm{C} / \mathrm{N}$ ratio also varies through the soil profile. They are typically higher in litterfall and decrease in SOM during humification (Snowdon et al., 2005; Boström et al., 2007; Yang et al., 2010). Selective degradation changes the stable $C$ isotope ratios of SOM. Surface litter remains more depleted in ${ }^{13} \mathrm{C}$ than $\mathrm{SOM}$ (Lichtfouse et al., 1995) that is progressively enriched in ${ }^{13} \mathrm{C}$ with soil depth (Balesdent and Mariotti, 1996; Amiotte-Suchet et al., 1999, 2007). Highlighting the variations in concentrations and isotopic compositions of TOC (in solid and solute fractions) in soils could help to track the origin of organic carbon in small tropical rivers with respect to their hydrological stages (low or high water stages).

In this way, Guadeloupean soils and rivers provide an ideal opportunity to investigate the interactions between soil and river pools and fluxes (e.g., Rivé et al., 2013). The island of Guadeloupe, which presents surface soil horizons thoroughly enriched in organic matter (10-15\%; Colmet-Daage and Bernard, 1979), is frequently impacted by high intensity meteorological events such as tropical storms and cyclones (Zahibo et al., 2007) that accentuate soil erosion (Waterloo et al., 2006; Dawson et al., 2008; Hilton et al., 2008b; Lloret et al., 2011; Allemand et al., 2014). In order to determine the DOC sources according to different hydrological stages of Guadeloupean rivers, the present study focuses on the characterization (especially concentrations, and isotopic compositions) of organic carbon in SOM and soil solutions through soil profiles of two small watersheds with contrasted settings.

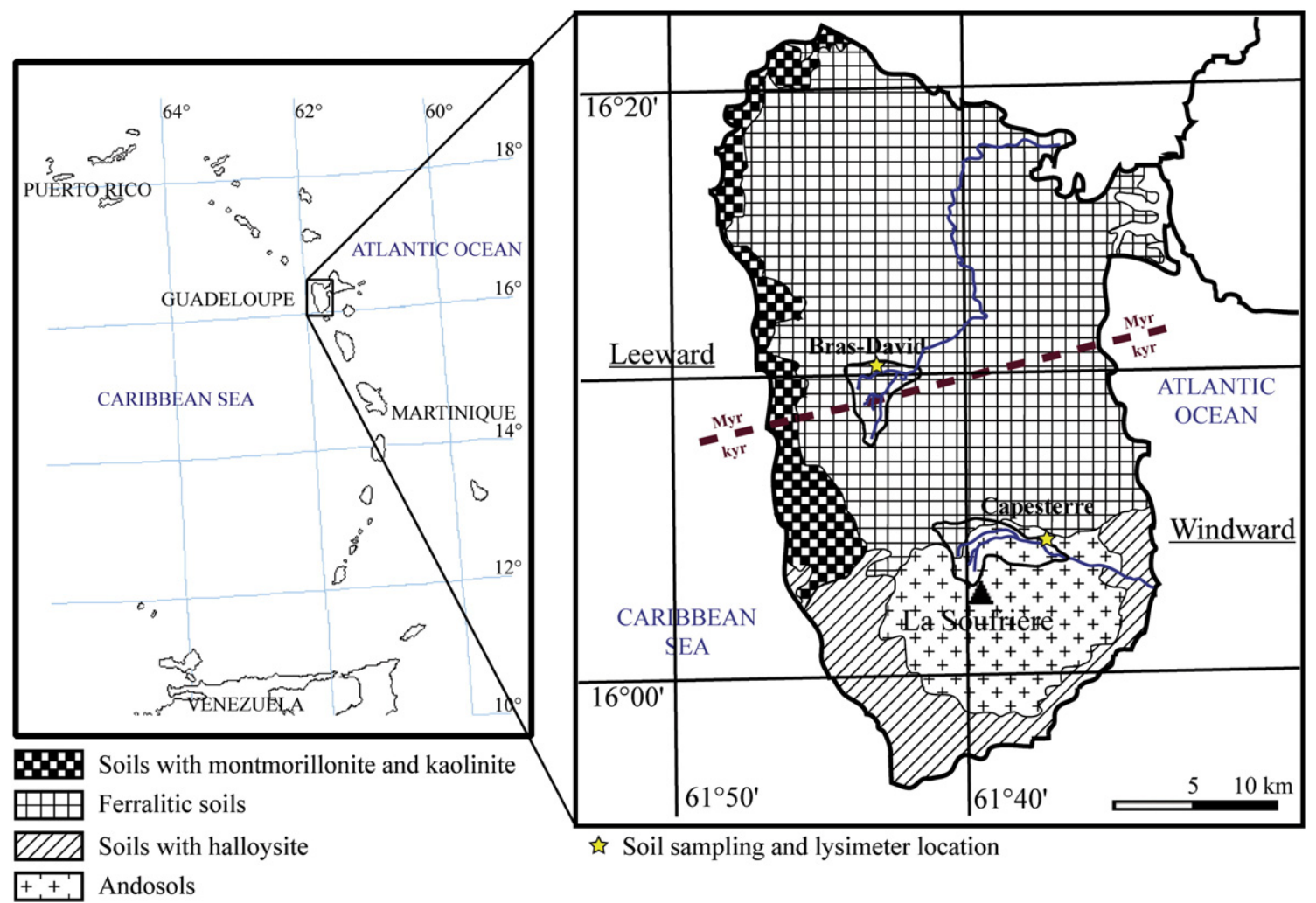

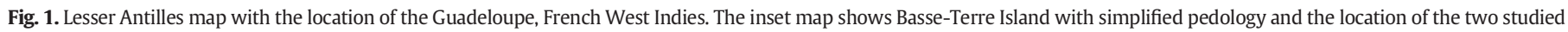
watersheds (Bras-David and Capesterre). 


\section{Study areas}

Guadeloupe is a part of the Lesser Antilles volcanic arc (Fig. 1), generated by the subduction of the North American plate beneath the Caribbean plate. The volcanic island of Basse-Terre, part of the Guadeloupe archipelago, belongs to the central segment of the arc (e.g., Feuillet et al., 2011). Basse-Terre Island is characterized by old geological formations in its northern part and increasingly recent ones near the present-day volcano: La Soufrière, which is located in its southern part (Samper et al., 2007, 2009). Our study is focused on two watersheds with different soil and river characteristics (Table 1 ), one located in the northern part of the island and another in the southern part (Fig. 1). These two watersheds are located in the National Park of Guadeloupe, and are monitored within the framework of the French Critical Zone Observatory OBSERA (INSU-CNRS) observatory devoted to the study of weathering and erosion in the French West Indies. This observatory belongs to the French network of monitored watersheds (RBV supported by INSU-CNRS and AllEnvi).

\subsection{Climate and hydrology}

Basse-Terre Island is characterized by a wet tropical climate, with a mean annual temperature and humidity of ca. $23{ }^{\circ} \mathrm{C}$ and $75 \%$, respectively (Plaisir et al., 2003). The average annual precipitation of the last decade ranges from 1500 to $7000 \mathrm{~mm} \mathrm{yr}^{-1}$, depending on the topography (Clergue et al., 2015; Dessert et al., 2015). Climate is characterized by two seasons: a dry season from January to June and a wet and rainy season from July to December (representing about $60 \%$ of the total annual precipitation, MétéoFrance data). During the wet season, hurricanes and tropical depressions produce heavy rainfall events (Zahibo et al., 2007), which play a major role for soil weathering and erosion. The spatial distribution of precipitation is strongly influenced by easterly winds and topography. The BrasDavid and the Capesterre watersheds are located on the windward coast influenced by easterly winds and high annual precipitation, between 2000 and $4300 \mathrm{~mm} \mathrm{yr}^{-1}$ (Météo France data). Runoff represents about $60 \%$ of the precipitation. The discharges of the studied rivers are monitored by DREAL (French Water Survey agency; http://www.hydro.eaufrance.fr).

\subsection{Vegetation cover, geology, and soils}

Located in the National Park of Guadeloupe, the vegetation cover of the two studied watersheds is mainly tropical rainforest and is dominated by C3 photosynthetic pathway plants, including Dichapetalaceae (Tapura latifolia), Euphorbiaceae (Richeria grandis, Amanoa caribaea), Burseraceae (Dacryodes excelsa), Sapotaceae (Pouteria pallida), and Annonaceae (Guatteria caribaea) (Rousteau et al., 1994; Rousteau, 1996).
The geological basement of the Bras-David watershed is composed of Pleistocene andesitic and dacitic (Samper et al., 2007, 2009), and covered by thick ferralitic soils (> $15 \mathrm{~m}$; Colmet-Daage and Bernard, 1979). These soils were previously studied (Henriet et al., 2008; Buss et al., 2010; Sak et al., 2010; Opfergelt et al., 2012; Clergue et al., 2015) and consist of highly weathered volcanoclastic debris flows containing rocky clasts at various stages of weathering. Clays, dominantly halloysite, represent about $75 \%$ wt of the mineralogical content and nonclays are almost entirely Fe(III)-hydroxides and quartz/cristobalite. The Capesterre watershed is underlain by andesitic rocks linked to late Pleistocene volcanism (Samper et al., 2007). Because of the steep slopes of the recent volcanic rocks (49\%; Plaisir et al., 2003), soils in this region are dominated by thin Andosols ( $<1 \mathrm{~m}$; Colmet-Daage and Bernard, 1979; Cattan et al., 2007; Cabidoche et al., 2009).

\section{Materials and methods}

\subsection{Sample collection}

\subsubsection{Litter and soil material sampling}

Two soil cores, representative of the two main soil types (ferralitic and Andosol), were sampled (Fig. 1) to analyze the TOC and total nitrogen (TN) concentrations and the stable carbon isotope composition $\left(\delta^{13} \mathrm{C}\right)$ of litter and SOM. The soil profiles were sampled (during the installation of lysimeters) every $\sim 15$ or $~ 30 \mathrm{~cm}(1 / 2$ or $1 \mathrm{ft})$, with a handauger at $0.15-0.91 \mathrm{~m}$ and $0.15-12.50 \mathrm{~m}$ soil depths for Capesterre and Bras-David watersheds, respectively. In addition, larger amounts of topsoil layers (from 0 to $30 \mathrm{~cm}$ ) were also sampled every $5-10 \mathrm{~cm}$ in pits. All soil samples were air-dried, sieved to $2 \mathrm{~mm}$, split with a sample divider, and homogenized by grinding at the USGS Menlo Park Campus (California, USA). Litter material from the two watersheds was collected in plastic bags and was rapidly air-dried to avoid mould development, then ground.

\subsubsection{Soil solution sampling}

Vadose zone pore waters were collected approximately monthly during 2007 and 2008 from $5 \mathrm{~cm}$ diameter nested porous-cup suction water samplers (Soil Moisture Inc., Santa Barbara, CA) (referred to as lysimeters hereafter). These lysimeters were placed in hand-augered holes at depths from 0.15 to $0.91 \mathrm{~m}$ and from 0.15 to $12.50 \mathrm{~m}$ for Capesterre and Bras-David sites, respectively. Soil solution characteristics were obtained by extracting soils with milliQ water following the procedure in Bardy (2008) or using a $\mathrm{Ca}\left(\mathrm{NO}_{3}\right)_{2}$ solution at $4.6 \times 10^{-3} \mathrm{M}$ according to Zsolnay (2003). The solution/ soil ratio and the time of extraction are reported in Table 2 . Soil solution samples used for DOC concentrations and $\delta^{13} \mathrm{C}$ measurements were filtered through glass fiber filters (GF/F Whatman ${ }^{\circledR}$ by Schleicher \& Schuell cutoff $0.7 \mu \mathrm{m}$ ) and acidified with concentrated $\mathrm{H}_{3} \mathrm{PO}_{4}(85 \%)$ in pre-cleaned and pre-combusted glass bottles, and stored at $4{ }^{\circ} \mathrm{C}$ in the dark.

Table 1

Watershed characteristics.

\begin{tabular}{|c|c|c|c|c|c|c|c|c|c|c|c|c|}
\hline \multirow[t]{3}{*}{ Sites } & \multirow[t]{3}{*}{ Latitude } & \multirow[t]{3}{*}{ Longitude } & \multirow[t]{3}{*}{ Area, $\mathrm{km}^{2}$} & \multirow[t]{3}{*}{ Elevation, m } & \multirow[t]{3}{*}{ Age of bedrock ${ }^{\mathrm{a}}$, Myrs } & \multicolumn{4}{|l|}{ Slopes $^{\mathrm{b}}$} & \multicolumn{3}{|c|}{ Vegetation $^{\mathrm{c}}$} \\
\hline & & & & & & $0-24 \%$ & $25-48 \%$ & 49-99\% & $>99 \%$ & Thickets & Altimountain Forest & Rainforest \\
\hline & & & & & & \multicolumn{4}{|c|}{$\%$ surface } & \multicolumn{3}{|l|}{$\%$ surface } \\
\hline Bras-David & $\mathrm{N} 16^{\circ} 10^{\prime} 33.6^{\prime \prime}$ & W61 $61^{\circ} 41^{\prime} 34.8^{\prime \prime}$ & 11.3 & $228-1088$ & 1.460 & 38 & 48 & & 0 & & 35 & 65 \\
\hline Capesterre & $\mathrm{N} 16^{\circ} 04^{\prime} 18.0^{\prime \prime}$ & W61 $1^{\circ} 36^{\prime} 34.1^{\prime \prime}$ & 16.6 & $200-1342$ & 0.554 & 18 & 32 & 33 & 5 & 33 & 39 & 29 \\
\hline
\end{tabular}

\footnotetext{
a Samper et al. (2007).

b Plaisir et al. (2003)

c Rousteau et al. (1994); Rousteau (1996).
} 
Table 2

Characteristics of milliQ water and $\mathrm{Ca}\left(\mathrm{NO}_{3}\right)_{2}$ extractions.

\begin{tabular}{lcc}
\hline Extraction & $\begin{array}{c}\text { milliQ water } \\
\text { Bardy (2008) }\end{array}$ & $\begin{array}{l}\mathrm{Ca}\left(\mathrm{NO}_{3}\right)_{2} \\
\text { Zsolnay (2003) }\end{array}$ \\
\hline $\begin{array}{ccc}\text { Solution/soil }\left(\mathrm{mL} \mathrm{g}^{-1} \text { of dry soil) }\right. \\
\text { Extraction time }\end{array}$ & 3 & 2 \\
Centrifugation time & $12 \mathrm{~h}$ & $10 \mathrm{~min}$ \\
& $20 \mathrm{~min}$ & $10 \mathrm{~min}$ \\
\hline
\end{tabular}

\subsubsection{River sampling}

Pristine water samples were collected upstream of any anthropogenic activities at the outlet of each watershed (Fig. 1). Surface water was sampled manually from 2007 to 2010 at different hydrological stages corresponding to low water and flood levels (Lloret et al., 2011, 2013; Dessert et al., 2015). An automatic water sampler, ISCO-6712, was set up on the Capesterre River to sample the largest number of extreme meteorological and hydrological events. It allowed the sampling of 27 flood events, including 5 extreme events during which up to 24 samples were taken (from every 15 min to $2 \mathrm{~h}$ ). Water samples used for the measurement of DOC concentrations and $\delta{ }^{13} \mathrm{C}$ measurements were filtered, acidified and stored as for soil solution sampling.

\subsection{Analytical methods}

TOC and TN concentrations of litter and SOM were measured using an elemental analyzer (Thermo Scientific Flash 2000), after checking that samples are carbonates free (controlled under acid vapor). The detection limit was $<5 \%$.

The $\delta^{13} \mathrm{C}_{\mathrm{TOC}}$ values were measured twice:

- at the Equipe de Géochimie des Isotopes Stables (LGIS, IPGP, France), using an IR-MS Finnigan MAT 253 coupled with an elemental analyzer Thermo Flash EA 1112 Series.

- at the Institut d'Ecologie et des Sciences de l'Environnement de Paris (iEES, UPMC, France), using an IR-MS Sira 10 Fisons coupled with an elemental analyzer Carlo-Erba Na-1500 NC.

Results are reported in per mil (\%) relative to the Pee Dee Belemnite (PDB) standard with a precision of $0.3 \%$. The results of the two labs were very similar $( \pm 0.2 \%$ ), and data reported in this study are averages of these two measurements.

The DOC concentrations from soil solutions or river waters were measured using a Shimadzu TOC-VCSH analyzer (Sugimura and Suzuki, 1988). The detection limit was $0.24 \mathrm{mg} \mathrm{L}^{-1}$ and the precision was $2 \%$. The $\delta^{13} C_{\text {Doc }}$ was measured at the "Institut des Sciences de la Terre d'Orléans" (ISTO, France) with an IR-MS Delta V Advantage coupled with a LC-Isolink interface (both Thermo Scientific) and an HPLC system serving as a pump for the carrier flow. Aliquots of $100 \mu \mathrm{L}$ of filtered and acidified sample water were directly injected in bulk mode and monitored in continuous flow (Albéric et al., 2010). The standards used for the $\delta^{13} C_{\text {Doc }}$ measurements were the internal standard from ISTO $\left(\mathrm{NaHCO}_{3},-4.3 \%\right.$ ), a benzoic acid (-25.7\%), USGS-40 (L-glutamic acid, $-26.389 \%$ ), IAEA-C8 (oxalic acid, $-18.3 \%$ ), and IAEA-C6 (sucrose, -10.8\%). The precision of DOC isotopic compositions was $0.3 \%$.

Spectrophotometric analyses of liquid samples were conducted with a dual beam Evolution 600 UV/Vis Thermo Scientific spectrophotometer. An aliquot of each acidified water sample collected for the DOC measurements was used for the spectroscopic characterization of the dissolved organic matter (DOM). Samples were placed in a $1 \mathrm{~cm}$ quartz window "cuvette" and scanned from 200 to $600 \mathrm{~nm}$, with $1 \mathrm{~nm}$ resolution (Chin et al., 1994). The percentages of aromatic carbon and the hydrophobic fraction of DOM were estimated from the UV-Vis absorbance data, with empirical relationships (Chin et al., 1994). Different wavelengths were selected (254, 270, and $280 \mathrm{~nm}$ ) to highlight the markers of organic matter. The absorbance at these different wavelengths defined as SUVA (Specific UV absorbance) is calculated with the following formula:

$\mathrm{SUVA}_{i}=\frac{\text { Absorbance at wavelength } \mathrm{i}\left(\mathrm{cm}^{-1}\right)}{\text { DOC concentration }\left(\mathrm{mg} \mathrm{L}^{-1}\right)}$ (i.e.SUVA $\left.{ }_{254}, \mathrm{SUVA}_{270}, \mathrm{SUVA}_{280}\right)$

\section{Results}

\subsection{Organic carbon and total nitrogen distributions through soil profiles}

\subsubsection{TOC and TN in litter and SOM}

For the Bras-David site, the mean organic carbon and nitrogen contents in the litter layers are $395 \pm 3 \mathrm{~g} \mathrm{~kg}^{-1}$ and $12.8 \pm 0.2 \mathrm{~g} \mathrm{~kg}^{-1}$, respectively, corresponding to a $\mathrm{C} / \mathrm{N}$ ( or TOC/TN) ratio of $30.8 \pm 0.6$ (Table 3 ). For Capesterre, they averaged $409 \pm 6 \mathrm{~g} \mathrm{~kg}^{-1}$ and $15.9 \pm 0.1 \mathrm{~g} \mathrm{~kg}^{-1}$, respectively, corresponding to a $\mathrm{C} / \mathrm{N}$ ratio of $25.8 \pm 0.5$ (Table 4 ). The TOC content of the Bras-David ferralitic soil decreases within the top two meters ranging 92 to $1.7 \mathrm{~g} \mathrm{~kg}^{-1}$ (Table 3). For soil depths between 2.0 and $12.5 \mathrm{~m}$, the TOC content is $<3.7 \mathrm{~g} \mathrm{~kg}^{-1}$ (range: ca. 0.9-3.7). Similarly, TN contents are higher within the top two meters (range: ca. 0.1$5.5 \mathrm{~g} \mathrm{~kg}^{-1}$ ), a decrease to $0.1 \mathrm{~g} \mathrm{~kg}^{-1}$ for deeper horizons. Consequently, the $\mathrm{C} / \mathrm{N}$ ratio remains relatively constant through the soil profile (ca. $12.7 \pm 3.2$ ) (Table 3). For the Capesterre soil, the highest TOC and TN contents are found in the topsoil (0.00-0.20 m depth) where they reached more than $23.6 \mathrm{~g} \mathrm{~kg}^{-1}$ and $2.3 \mathrm{~g} \mathrm{~kg}^{-1}$, respectively, then they decrease progressively to $5.6 \mathrm{~g} \mathrm{~kg}^{-1}$ and $0.4 \mathrm{~g} \mathrm{~kg}^{-1}$, respectively, in 0.20 $0.91 \mathrm{~m}$ soil horizons (Table 4 ). As in the Bras-David ferralitic soil, the $\mathrm{C} / \mathrm{N}$ ratio in the Capesterre Andosol remains constant through the soil profile (ca. $11.4 \pm 1.4$ ) (Table 4).

The TOC and TN stocks for the upper $30 \mathrm{~cm}$ were calculated from concentrations (c), dry densities $\left(d=0.650\right.$ and $0.87510^{3} \mathrm{~kg} \mathrm{~m}^{-3}$ for 0-15 cm and 15-30 cm, respectively; Buss et al., 2010) and thicknesses $(t)$ of each horizon, using the following formula:

Stock $=c \times d \times t$

TOC and TN stocks in the Bras-David ferralitic soil are almost 11,600 \pm 7500 and $800 \pm 450 \mathrm{Mg} \mathrm{km}^{-2}$, respectively, and in the Capesterre Andosol are almost $11,200 \pm 6000$ and $1000 \pm 500 \mathrm{Mg} \mathrm{km}$, respectively.

The carbon isotopic composition of SOM for the Bras-David ferralitic soil and the Capesterre Andosol varies between -27.3\% and -24.2\%。 (Tables 3 and 4) and is representative of degraded and humified ${ }^{13} \mathrm{C}$ enriched organic matter derived from trees and understory C3 photosynthetic pathway plants (Deines, 1980; Balesdent et al., 1993) that compose the Guadeloupean rainforest. Additional evidence is pictured by the even more ${ }^{13} \mathrm{C}$-depleted (less degraded) composition of litterfall for both soils (ca. $-29.0 \%$ o to $-29.7 \%$, Tables 3 and 4 ).

\subsubsection{DOC in soil solutions}

The DOC concentrations in soil solutions obtained by milliQ water and $\mathrm{Ca}\left(\mathrm{NO}_{3}\right)_{2}$ extractions are similar and follow the same trends through the two soil profiles (Tables 3 and 4). For the Bras-David ferralitic soil, the DOC concentrations decrease with depth from 91.3 to $5.2 \mathrm{mg} \mathrm{L}^{-1}$ within the upper two meters and remain constant below $2 \mathrm{~m}$ with a value of $5.8 \pm 1.5 \mathrm{mg} \mathrm{L}^{-1}$ (Table 3 ). For the Capesterre Andosol, the DOC concentrations range from 3.2 to $28.9 \mathrm{mg} \mathrm{L}^{-1}$ (Table 4), exhibiting the highest values within the upper $30 \mathrm{~cm}$ and decreasing with depth.

The DOC concentrations in soil solutions sampled from lysimeters are lower than those obtained by soil extractions, but the trends through the two soil profiles are similar for both techniques (Tables 3 
Table 3

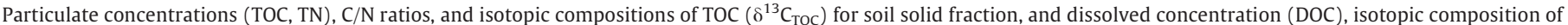
$\mathrm{DOC}\left(\delta^{13} \mathrm{C}_{\mathrm{DOC}}\right)$ and percentage of aromaticity for liquid fractions obtained by lysimeters and lab extractions $\left(\right.$ water and $\left.\left.\mathrm{Ca}\left(\mathrm{NO}_{3}\right)_{2}\right)\right)$ for Bras-David soil.

\begin{tabular}{|c|c|c|c|c|c|c|c|c|c|c|c|c|}
\hline \multirow{2}{*}{\multicolumn{5}{|c|}{ Solid fraction }} & \multicolumn{8}{|c|}{ Liquid fraction } \\
\hline & & & & & \multicolumn{3}{|l|}{ Lysimeters } & \multicolumn{3}{|c|}{ Water extractions } & \multicolumn{2}{|c|}{$\mathrm{Ca}\left(\mathrm{NO}_{3}\right)_{2}$ extractions } \\
\hline Depth, cm & TOC, $\mathrm{g} \mathrm{kg}^{-1}$ & $\mathrm{TN}, \mathrm{g} \mathrm{kg}^{-1}$ & $\mathrm{C} / \mathrm{N}$ & $\delta^{13} C_{\text {TOC, }} \%$ & $\mathrm{DOC}, \mathrm{mg} \mathrm{L}^{-1}$ & $\delta^{13} C_{\text {DOC }} \%$ & Aromaticity, \% & DOC, $\mathrm{mg} \mathrm{L}^{-1}$ & $\delta^{13} C_{\text {DOC, }} \%$ & Aromaticity, \% & DOC, $\mathrm{mg} \mathrm{L}^{-1}$ & $\delta^{13} C_{\text {DOC, }} \%$ \\
\hline Litter & 394.50 & 12.80 & 30.8 & -29.7 & & & & & & & & \\
\hline $0-5$ & 91.92 & 5.48 & 16.8 & & & & & & & & 77.92 & \\
\hline $5-10$ & 48.66 & 3.91 & 12.5 & & & & & & & & & \\
\hline $10-20$ & 17.95 & 1.26 & 14.3 & & & & & & & & & \\
\hline $20-25$ & 17.29 & 1,23 & 14.1 & & & & & & & & & \\
\hline 15 & 57.59 & 4,01 & 14.4 & -27.3 & 1.62 & -31.4 & 21.7 & 91.31 & -26.4 & 9.2 & & -28.6 \\
\hline 30 & 32.61 & 2.30 & 14.2 & -27.2 & 0.95 & -33.1 & 32.1 & 55.81 & -26.3 & 7.7 & 57.77 & -28.2 \\
\hline 61 & 8.79 & 0.53 & 16.5 & -26.3 & 1.69 & -31.2 & 17.6 & 8.66 & -27.3 & 9.9 & 12.14 & -25.8 \\
\hline 91 & 7.71 & 0.49 & 15.6 & -26.6 & 0.88 & -33.1 & 18.0 & 8.25 & -28.4 & 11.8 & 10.62 & -26.7 \\
\hline 122 & 3.96 & 0.24 & 16.8 & -26.2 & 0.69 & -32.6 & 24.2 & 6.81 & -27.8 & 12.6 & 7.94 & -26.5 \\
\hline 152 & 2.32 & 0.15 & 15.0 & -26.5 & 0.61 & -33.8 & 31.7 & 6.50 & -27.9 & 12.9 & 7.50 & -26.6 \\
\hline 183 & 1.72 & 0.13 & 13.4 & -25.6 & 0.77 & -33.0 & 24.0 & 3.69 & -27.8 & 19.5 & 4.66 & -26.0 \\
\hline 213 & 1.89 & 0.13 & 14.2 & -25.7 & & & & 5.21 & & 13.7 & 5.90 & -26.6 \\
\hline 244 & 3.71 & 0.24 & 15.6 & -26.5 & & & & 6.76 & & 11.4 & 6.73 & -25.8 \\
\hline 274 & 2.41 & 0.16 & 14.6 & -26.8 & 0.60 & -33.2 & 23.3 & 5.88 & -27.4 & 13.0 & 6.82 & -25.9 \\
\hline 305 & 3.34 & 0.36 & 9.3 & -25.8 & & & & 3.95 & -27.9 & 15.8 & 5.50 & -26.6 \\
\hline 344 & & & & & 0.60 & -33.2 & 24.0 & & & & & \\
\hline 366 & 1.68 & 0.13 & 13.0 & -24.8 & & & & 4.35 & -28.1 & 18.1 & 4.95 & -26.6 \\
\hline 427 & 2.93 & 0.32 & 9.1 & -25.9 & & & & 5.32 & -28.2 & 14.8 & 4.52 & -27.1 \\
\hline 457 & & & & & 0.62 & -33.8 & 23.2 & & & & & \\
\hline 488 & 3.72 & 0.24 & 15.5 & -24.6 & & & & 4.72 & -28.1 & 15.8 & 4.34 & -26.8 \\
\hline 549 & 1.91 & 0.15 & 13.0 & -24.7 & & & & 7.04 & & 12.8 & 5.55 & -27.1 \\
\hline 610 & 1.29 & 0.14 & 9.4 & -26.5 & & & & 6.85 & -28.2 & 13.2 & & -27.0 \\
\hline 671 & 1.72 & 0.18 & 9.7 & -25.8 & & & & 5.44 & & 15.3 & 6.73 & -26.9 \\
\hline 732 & & & & & & & & 4.36 & & 14.5 & 4.22 & -26.9 \\
\hline 792 & 1.30 & 0.13 & 9.9 & -25.7 & & & & 2.92 & & 20.2 & 8.33 & -27.6 \\
\hline 823 & & & & & 0.66 & -32.9 & 28.2 & & & & & \\
\hline 853 & 1.73 & 0.18 & 9.4 & -25.8 & & & & 4.45 & -28.2 & 17.6 & 5.32 & -26.9 \\
\hline 914 & 1.41 & 0.14 & 10.4 & -26.4 & & & & 4.56 & & 15.3 & 7.01 & -27.2 \\
\hline 975 & 0.88 & 0.09 & 9.6 & -24.7 & & & & 3.09 & -28.1 & 17.8 & 5.64 & -27.2 \\
\hline 1036 & 1.14 & 0.10 & 11.8 & -25.1 & & & & 5.67 & & 13.2 & 6.12 & -27.4 \\
\hline 1097 & 1.00 & 0.10 & 9.6 & -27.3 & & & & 5.41 & & 13.0 & 7.32 & -27.6 \\
\hline 1158 & 0.99 & 0.10 & 10.3 & -24.2 & & & & 4.84 & & 14.4 & 6.13 & -26.8 \\
\hline 1219 & 2.51 & 0.34 & 7.3 & -26.3 & & & & 6.92 & & 11.9 & 7.71 & -27.2 \\
\hline 1250 & 2.70 & 0.31 & 8.7 & -25.4 & 0.51 & & 32.6 & 6.65 & -28.2 & 13.5 & 10.69 & -27.5 \\
\hline
\end{tabular}

and 4). For the Bras-David ferralitic soil, the DOC concentrations in soil solutions sampled by lysimeters decrease with depth from 1.46 to $0.65 \mathrm{mg} \mathrm{L}^{-1}$ within the upper two meters and remain constant (ca. $0.69 \pm 0.08 \mathrm{mg} \mathrm{L}^{-1}$ ) below $2 \mathrm{~m}$ (Table 3). For the Capesterre Andosol, the DOC concentrations in soil solutions decrease with depth from 1.45 to $0.88 \mathrm{mg} \mathrm{L}^{-1}$ (Table 4 ).

For the two soil profiles, the isotopic compositions of DOC obtained by extractions and SOM are comparable, with $\delta^{13} \mathrm{C}$ values ranging from $-28.6 \%$ o to $-26.3 \%$ o and from $-28.3 \%$ o to $-25.8 \%$ of the soil solutions of Bras-David ferralitic soil and the Capesterre Andosol, respectively
(Tables 3 and 4). The DOC sampled from lysimeters is, however, systematically depleted in ${ }^{13} \mathrm{C}$ compared to DOC obtained by extractions, with $\delta^{13} \mathrm{C}$ values of $-33.8 \%$ to $-31.2 \%$ and $-33.1 \%$ o to $-30.6 \%$ or for the BrasDavid ferralitic soil and the Capesterre Andosol, respectively (Tables 3 and 4).

The percentage of aromatic organic carbon, or "aromaticity" of the dissolved organic matter (DOM) was calculated by averaging the values following the relationships for various DOM types from Chin et al. (1994); Peuravuori and Pihlaja (1997), and Weishaar et al. (2003). The DOM is more aromatic in soil solution sampled from lysimeters

Table 4

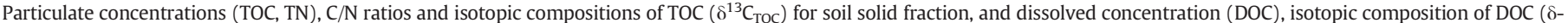
${ }^{13} \mathrm{C}_{\mathrm{DoC}}$ ), and percentage of aromaticity for liquid fractions obtained by lysimeters and lab extractions (water and $\left.\mathrm{Ca}\left(\mathrm{NO}_{3}\right)_{2}\right)$ ) for Capesterre soil.

\begin{tabular}{|c|c|c|c|c|c|c|c|c|c|c|c|c|}
\hline \multirow{2}{*}{\multicolumn{5}{|c|}{ Solid fraction }} & \multicolumn{8}{|c|}{ Liquid fraction } \\
\hline & & & & & \multicolumn{3}{|l|}{ Lysimeters } & \multicolumn{3}{|c|}{ Water extractions } & \multicolumn{2}{|c|}{$\mathrm{Ca}\left(\mathrm{NO}_{3}\right)_{2}$ extractions } \\
\hline Depth, cm & $\mathrm{TOC}, \mathrm{g} \mathrm{kg}^{-1}$ & $\mathrm{TN}, \mathrm{g} \mathrm{kg}^{-1}$ & $\mathrm{C} / \mathrm{N}$ & $\delta^{13} C_{\text {TOC, }} \%$ & $\mathrm{DOC}, \mathrm{mg} \mathrm{L}^{-1}$ & $\delta^{13} C_{\text {DOC }} \%$ & Aromaticity, \% & $\mathrm{DOC}, \mathrm{mg} \mathrm{L}^{-1}$ & $\delta^{13} C_{\text {DOC }}, \%$ & Aromaticity, \% & $\mathrm{DOC}, \mathrm{mg} \mathrm{L}^{-1}$ & $\delta^{13} C_{\text {DOC }}, \%$ \\
\hline Litter & 408.60 & 15.90 & 25.8 & -29.0 & & & & & & & 73.97 & \\
\hline $0-5$ & 74.29 & 6.19 & 12.0 & & & & & & & & & \\
\hline $5-10$ & 53.86 & 5.14 & 10.5 & & & & & & & & & \\
\hline $10-15$ & 39.05 & 3.65 & 10.7 & & & & & & & & & \\
\hline $15-20$ & 23.60 & 2.34 & 10.1 & & & & & & & & & \\
\hline $20-30$ & 20.55 & 1.92 & 10.7 & & & & & & & & & \\
\hline 15 & 25.50 & 2.64 & 9.7 & -26.6 & 1.75 & -30.6 & 16.4 & 28.90 & -26.9 & 7.9 & 28.38 & -25.8 \\
\hline 30 & 26.85 & 2.54 & 10.6 & -26.9 & 0.78 & -32.9 & 24.3 & 24.02 & -27.7 & 7.2 & 28.02 & -26.5 \\
\hline 46 & 10.29 & 0.92 & 11.2 & -26.4 & & & & 7.40 & & 9.3 & 5.88 & -26.4 \\
\hline 61 & 7.39 & 0.61 & 12.1 & -25.4 & 0.58 & -33.1 & 32.5 & 6.13 & -28.2 & 14.2 & 4.59 & -26.2 \\
\hline 76 & 5.83 & 0.40 & 14.6 & -25.2 & & & & 4.79 & & 11.6 & 2.95 & -26.5 \\
\hline 91 & 5.63 & 0.44 & 12.9 & -25.7 & 0.76 & -32.8 & 19.3 & 6.35 & -28.3 & 11.8 & 3.24 & -26.4 \\
\hline
\end{tabular}




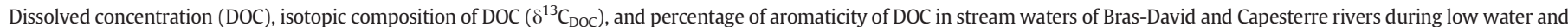
flood levels from 2007 to 2010 (Lloret et al., 2011, 2013).

\begin{tabular}{|c|c|c|c|c|c|c|}
\hline \multirow[b]{2}{*}{ Sites } & \multicolumn{3}{|c|}{ Low water level } & \multicolumn{3}{|l|}{ Flood } \\
\hline & $\mathrm{DOC}, \mathrm{mg} \mathrm{L}^{-1}$ & $\delta^{13} C_{\text {DOC }} \%$ & Aromaticity, \% & $\mathrm{DOC}, \mathrm{mg} \mathrm{L}^{-1}$ & $\delta^{13} C_{\text {DOC }} \%$ & Aromaticity, \% \\
\hline Bras-David & $\begin{array}{c}N=46 \\
0.46 \text { to } 5.31\end{array}$ & $\begin{array}{c}N=5 \\
-38.9 \text { to }-30.4\end{array}$ & $\begin{array}{c}N=26 \\
18.3 \text { to } 100.4\end{array}$ & $\begin{array}{c}N=8 \\
0.69 \text { to } 3.23\end{array}$ & $\begin{array}{c}N=4 \\
-30.9 \text { to }-29.4\end{array}$ & $\begin{array}{c}N=4 \\
15.8 \text { to } 73.7\end{array}$ \\
\hline Capesterre & $\begin{array}{c}N=175 \\
0.46 \text { to } 3.75\end{array}$ & $\begin{array}{c}N=25 \\
-34.4 \text { to }-27.3\end{array}$ & $\begin{array}{c}N=6 \\
33.1 \text { to } 54.4\end{array}$ & $\begin{array}{c}N=243 \\
0.96 \text { to } 5.75\end{array}$ & $\begin{array}{c}N=20 \\
-30.5 \text { to }-27.2\end{array}$ & $\begin{array}{c}N=2 \\
35.3 \text { to } 39.1\end{array}$ \\
\hline
\end{tabular}

than those obtained by milliQ water extractions. In the lysimeter samples, the aromaticity is $18 \%$ to $33 \%$ and $16 \%$ to $33 \%$ for the Bras-David ferralitic soil and the Capesterre Andosol, respectively. In milliQ water extractions, the aromaticity is $8 \%$ to $20 \%$ and $7 \%$ to $14 \%$, for the BrasDavid ferralitic soil and the Capesterre Andosol, respectively (Tables 3 and 4). Similarly, we have also observed that the percentage of hydrophobic organic carbon (calculated following methods from Chin et al. (1994), and Weishaar et al. (2003)) for the two soil profiles is more significant for solutions collected from lysimeters than from extractions.

\subsection{DOC in river waters}

The DOC concentrations for the two studied Guadeloupean rivers were reported in studies of Lloret et al. $(2011,2013)$ and are summarized in Table 5. These rivers exhibit comparable DOC concentrations, between 0.46 and $5.75 \mathrm{mg} \mathrm{L}^{-1}$. During low water level, the mean DOC concentrations are $0.76 \pm 0.28 \mathrm{mg} \mathrm{L}^{-1}$ and $1.40 \pm 0.60 \mathrm{mg} \mathrm{L}^{-1}$ for the Bras-David River and the Capesterre River, respectively. During flood events, the mean DOC concentrations are similar for both rivers, with $2.71 \pm 1.37 \mathrm{mg} \mathrm{L}^{-1}$ for the Bras-David River and $2.24 \pm 0.66 \mathrm{mg} \mathrm{L}^{-1}$ for the Capesterre River.

The isotopic compositions of DOC in the rivers range from $-38.9 \%$ o to $-27.2 \%$, with $\delta{ }^{13} \mathrm{C}$ values, which are more depleted in ${ }^{13} \mathrm{C}$ during low water level than flood events (Table 5).

For both rivers, the aromaticity ranges from $18.3 \%$ to $100.4 \%$, but no differences were observed between low water level and floods (Table 5 ). Again, the percentage of hydrophobic organic carbon for both rivers is not related to hydrological levels, and ranges from $50.6 \%$ to $139.0 \%$.

\section{Discussion}

The following discussion will first focus on the characteristics of the Guadeloupean SOM, and then on the comparison between soil solutions sampled by lysimeters and obtained by extractions. Finally, we will address the question of the sources of dissolved organic carbon according to the hydrological stages.

\subsection{Production and evolution of SOM in volcanic tropical soils}

For both sites, litter exhibits rather similar TOC (ca. $400 \mathrm{~g} \mathrm{~kg}^{-1}$ ) and TN (ca. $14.5 \mathrm{~g} \mathrm{~kg}^{-1}$ ) contents (Tables 3 and 4), which are close to those measured in other tropical forests (Schwartz, 1993). The $\mathrm{C} / \mathrm{N}$ ratios for litter samples (25.8-30.8, Tables 3 and 4) are lower than those usually observed for litterfall in tropical forests (38-43; Schwartz, 1993), indicating that fresh organic matter had likely partly decayed in litterfall before incorporation into soil organic matter.

The TOC and TN contents and the $\mathrm{C} / \mathrm{N}$ ratios are also similar for both soils (Tables 3 and 4 ) and are comparable to values measured in pristine forest soils in the East Kalimantan Province, Indonesia (Fujii et al., 2009), humid tropical primary forest soils in Sumatra (van Noordwijk et al., 1997), and ferralitic soils under tropical rainforest originate from different countries around the world like Brazil, Indonesia, Zaire (Kauffman et al., 1998). Several inferences can be made from these results:
- The decreases of TOC and TN contents and C/N ratios between litter and soils and with soil depth (Tables 3 and 4) reflect the ongoing decomposition or humification processes of organic matter in the soils.

- The low C/N ratios of the two Guadeloupean soils indicate a high degree of decomposition (Kauffman et al., 1998).

- The relatively constant $\mathrm{C} / \mathrm{N}$ ratios through the two soil profiles indicate that organic carbon and nitrogen are degraded at a similar rate.

For the upper $30 \mathrm{~cm}$ of soil profile, the carbon stocks in the Guadeloupean ferralitic soil and Andosol (11,600 and 11,200 $\mathrm{Mg} \mathrm{km}^{-2}$, respectively) are two times higher than values found for primary wet tropical forests (e.g., Baudin et al., 2007; Ngo et al., 2013). However, they are comparable to estimates given for soils of Martinique $\left(13,000 \mathrm{Mg} \mathrm{km}^{-2}\right.$; Blanchart and Bernoux, 2005). Moreover, Martinique and Guadeloupe islands are covered by a tropical rainforest with similar characteristics (e.g., climate, soil cover). These high carbon contents are probably due to soils formed with similar volcanic rocks coming from the same volcanic arc.

Litters are more depleted in ${ }^{13} \mathrm{C}$ than the upper $15 \mathrm{~cm}$ of both soils (Tables 3 and 4), a relationship which is generally observed worldwide (e.g., Ladyman and Harkness, 1980; Bellanger et al., 2004). During the decay of fresh organic matter (litter), the decomposers preferentially use the ${ }^{12} \mathrm{C}$, which results in ${ }^{13} \mathrm{C}$ enrichment of the remaining SOM. Accordingly, SOM is typically ${ }^{13} \mathrm{C}$-enriched by $1.5-4.3 \%$ 。 relative to homogenous plant and litter constituents (Lichtfouse et al., 1995).

For both soil profiles, the $\delta^{13} \mathrm{C}$ values of SOM $\left(\delta^{13} \mathrm{C}_{\mathrm{SOM}}\right)$ increased slightly (1.5\%) with depth within the top meter. This ${ }^{13} \mathrm{C}$ enrichment is negatively correlated with the TOC content. These results are similar to those observed by Balesdent et al. (1993); Balesdent and Mariotti (1996), for mainland French soils, and for other soils in equilibrium with C3 plants under tropical forests in Amazon basin (Andreux et al., 1990; Desjardins, 1991; Desjardins et al., 1994; Koutika et al., 1997). The observed pattern of ${ }^{13} \mathrm{C}$ enrichment over the top meter is typically interpreted as the stable carbon isotopic fractionation of SOM by decomposing organisms (Mariotti and Balesdent, 1990; Mariotti, 1991; Boutton, 1996) and is supported by the correlation between $\delta^{13} \mathrm{C}_{\mathrm{TOC}}$ and $\mathrm{LnC}$ for both soil profiles (Fig. 2a). This enrichment is controlled by different factors such as the molecular characteristics of the initial material (Agren et al., 1996), the degree of SOM decay (Blair et al., 1985), and the diversity of decomposers (Andrews et al., 2000). Alternatively, a differential mineralization of two carbon stocks in the soils, one labile and one more stable (Mariotti, 1991), may be involved, as highlighted by the correlation between $\delta^{13} \mathrm{C}_{\mathrm{TOC}}$ and $1 / \mathrm{C}$ for both sites (Fig. 2b). Finally, this trend may also result from the leaching of SOM by groundwater flow, which tends to preferentially remove the ${ }^{12} \mathrm{C}$ and leave a ${ }^{13} \mathrm{C}$-enriched SOM residue (Kaiser et al., 2001). The extent of carbon isotopic variations of these two Guadeloupean soils may reflect the following: (1) the high clay content typical of tropical soils (Schulte and Ruhiyat, 1998; Buss et al., 2010), (2) high net primary productivity, and so high soil microbial activity (Baudin et al., 2007), and (3) high annual precipitation resulting in high percolation fluxes and high adsorption potential (Shen, 1999; Neff and Asner, 2001). For the Capesterre Andosol, the dominant process that can be put forward is likely carbon isotopic fractionation during SOM decay (better correlation coefficient 

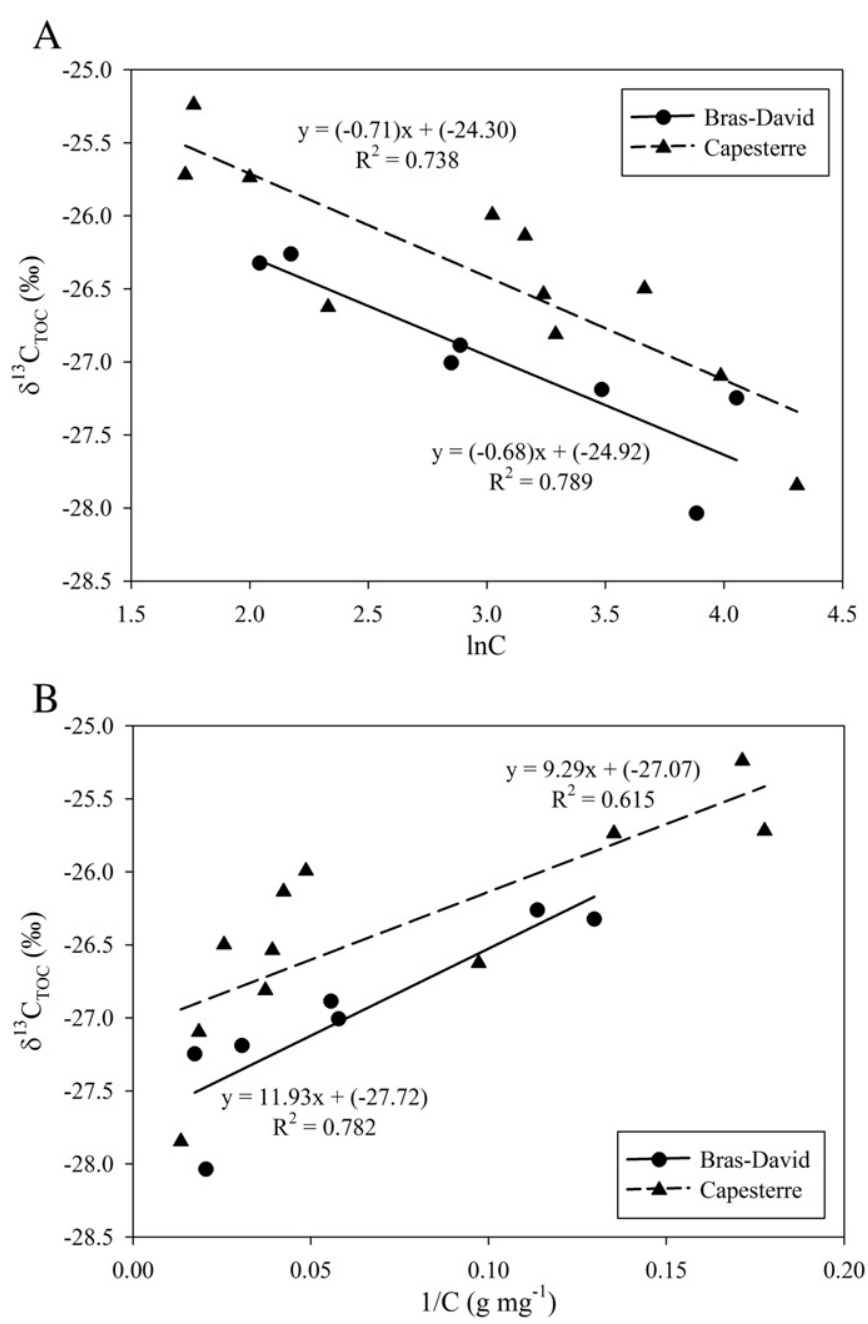

Fig. 2. Carbon isotopic composition of soil organic matter plotted as a function of $\ln C(\mathrm{a})$ and as a function of $1 / \mathrm{C}$ ratio (b), with $\mathrm{C}$ the organic carbon content in soil organic matter

than for mineralization, Fig. 2). However, for the Bras-David ferralitic soil, it is hard to solve what is the dominant process because the correlation coefficients (Fig. 2) are quite similar for the two processes of carbon isotopic fractionation origin (SOM decay or mineralization).

\subsection{DOC production and cycling in tropical volcanic soils}

The DOC concentrations obtained by milliQ water and $\mathrm{Ca}\left(\mathrm{NO}_{3}\right)_{2}$ extractions are very similar and follow the same decreasing trend as the TOC (Tables 3 and 4). These similarities could be explained by the extraction technique, which allow extracting the same fraction of dissolved organic matter. For the upper $30 \mathrm{~cm}$, the Capesterre Andosol contains less DOC than the Bras-David ferralitic soil, probably due to the enrichment of organic carbon in the surface layers of the BrasDavid ferralitic soil relative to the Capesterre Andosol. Moreover, ferralitic soils are generally more acidic than Andosols (Colmet-Daage and Lagache, 1965 , average $\mathrm{pH} 4.85 \pm 0.23$ and $5.74 \pm 0.19$ in soil solution of Bras-David soil and Capesterre soil, respectively) and thereby more effective at dissolving organic carbon. The dissolved organic matter in soil solutions collected by lysimeters could reflect the mobile fraction of organic matter (Zsolnay, 2003), whereas the extractions would extract both the mobile and immobile (complexed or adsorbed) fractions (Zsolnay, 2003), explaining the higher DOC concentrations for the extractions (Tables 3 and 4).

The extracted soil solutions are generally more depleted in ${ }^{13} \mathrm{C}$ than SOM, except in the upper $30 \mathrm{~cm}$ (Tables 3 and 4). This likely reflects the

preferential adsorption of carboxylic groups which are enriched in ${ }^{13} \mathrm{C}$, leaving the soil solution depleted in ${ }^{13} \mathrm{C}$ (Kaiser et al., 2001; Garten et al., 2000). There is, however, a carbon isotopic difference in the DOC between the two types of extraction. For both soils, the extracted milliQ water solutions are generally more depleted in ${ }^{13} \mathrm{C}$ than the extracted $\mathrm{Ca}\left(\mathrm{NO}_{3}\right)_{2}$ solutions (Tables 3 and 4 ). This observation shows that different fractions of dissolved organic matter are extracted by these two methods. Conversely, for both sites, increasing $\delta^{13} \mathrm{C}$ of SOM is observed with decreasing $\delta^{13} \mathrm{C}$ of DOC in lysimeter solutions (Tables 3 and 4 ). This trend was also observed by Ludwig et al. (2000) and attributed either to the preferential decay of labile substances or to the selective adsorption of carbon. During SOM decay, the soil solution produced is depleted in ${ }^{13} \mathrm{C}$ relative to SOM (Agren et al., 1996; Amiotte-Suchet et al., 2007). According to the second process, the preferential adsorption of the carboxylic groups enriched in ${ }^{13} \mathrm{C}$ (Kaiser et al., 2001) would also leave a soil solution depleted in ${ }^{13} \mathrm{C}$ (Garten et al., 2000).

The proportion of aromatic DOC is higher in soil solutions collected by lysimeters than in those extracted with milliQ water (Tables 3 and 4). In fact, dissolved organic matter in soil solutions obtained by milliQ water extraction can be represented by fulvic acids that are enriched in ${ }^{13} \mathrm{C}$ and less aromatic. The dissolved organic matter in soil solutions collected by lysimeters can be represented by humic acids (depleted in ${ }^{13} \mathrm{C}$ and more aromatic) (Nissenbaum and Kaplan, 1972; Flexor and Volkoff, 1977).

\subsection{DOC sources in small tropical volcanic rivers}

The DOC in stream waters results from the mixing of two sources, which are represented by soil solutions collected from lysimeters and by extractions (Fig. 3). During flood stage (Lloret et al., 2011, 2013), the streams are essentially fed by lixiviation of soil surface layers (represented by extracted soil solutions). During low water levels (Lloret et al., 2011, 2013), the streams are fed by groundwater (represented by soil solution collected from lysimeters).

Lixiviation of soil surface layers can be boosted by significant increases of intensity and duration of meteorological events, as has been

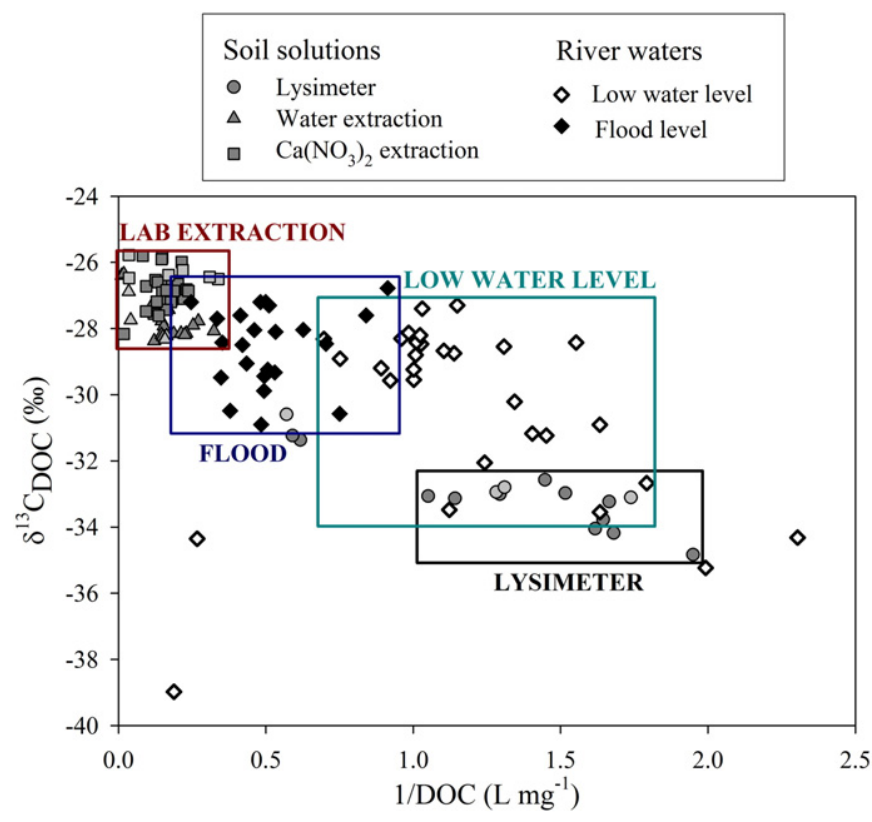

Fig. 3. Carbon isotopic composition of DOC in studied rivers for two hydrological stages (low water level and flood) and in soil solutions sampled from lysimeters and obtained by lab extractions. Soil solutions (lysimeters and lab extractions) are represented by dark grey and light grey symbols for Bras-David and Capesterre, respectively. 
observed for several decades (Emanuel, 2005; Webster et al., 2005). This can strongly favor the following:

- the release of top soil organic matter into rivers and increase in the DOC yields, which are similar to large rivers (Lloret et al., 2011, 2013). This terrestrial organic matter can be degraded by microbial organisms, preserved in continental margins and/or transported offshore (Hedges et al., 1997; Benner, 2004).

- the impoverishment of soil surface layers in nutrients can affect the long-term stability of the Guadeloupean tropical rainforest ecosystem.

For instance, the average soil organic carbon residence time is 580 years (Lloret et al., 2013), and an increase of extreme meteorological events will decrease this residence time and consequently release more labile organic matter in oceans.

Due to the geomorphic characteristics of Guadeloupean watersheds (strong relief, direct connection to the oceans), the meteorological events lead to specific hydrological processes as flash floods, which are limited in duration. Consequently, more than $2 / 3$ of the year, these rivers are at the low water level stage (Lloret et al., 2013) and DOC comes from groundwater.

The two river samples, collected during low water levels, which have very low $\delta^{13} \mathrm{C}$ and low 1:DOC ratio (Fig. 3), can be attributed to additional sources, likely primary production in the rivers $\left(\delta^{13} \mathrm{C}\right.$ of phytoplankton in natural river waters is $-35 \%$ o to $-25 \%$, Kendall et al., 2001) and the mineralization of leaves falling directly into the rivers $\left(\delta^{13} \mathrm{C}\right.$ of leaves is lower than of litter or soil, thus $<-25.8 \%$ o), respectively. This interpretation is supported by the observation of a biofilm on river stones during the low water periods.

\section{Conclusion}

This study shows clearly that there are different sources of DOC according to hydrological stages of the Guadeloupean rivers. These sources are deeply related to processes occur in soils. TOC and TN decrease with depth in the bulk soil, whereas the $\mathrm{C} / \mathrm{N}$ ratio remains relatively constant through the soil profile. The enrichment of $\delta^{13} \mathrm{C}$ of SOM with depth through the soil profile is consistent with the carbon isotopic fractionation of SOM by decomposing organisms, or the differential mineralization of both labile and stable carbon stocks in soils, or the leaching of SOM by groundwater flow.

The $\delta^{13} C_{\text {DOC }}$ of river water samples and soil solutions obtained by extraction and collected from lysimeters demonstrates that the DOC in rivers derives essentially from both the lixiviation of the soil surface layers during floods and from groundwater during low water levels. The dissolved organic matter in extracted soil solutions, which is represented by fulvic acids, is more enriched in ${ }^{13} \mathrm{C}$ and less aromatic than that from lysimeters, which is represented by humic acids. Another source with very low $\delta^{13} \mathrm{C}_{\mathrm{DOC}}$ and high $1 / \mathrm{DOC}$ ratios may also feed the rivers during low water levels. This additional source is likely to be either the internal primary production of the rivers or the mineralization of leaves that fall into the rivers. Further study of the $\delta^{13} \mathrm{C}$ of biofilms formed on river stones during low water periods may help to better constrain this other source.

Therefore, three main sources of DOC in rivers were identified in the particular case of small tropical mountainous watersheds. As it was demonstrated by Lloret et al. (2013), the DOC yields of Guadeloupean rivers are close to those of large tropical rivers, like the Amazon or the Orinoco. Consequently, identification of several DOC sources is a crucial point to better understand global carbon cycle.

\section{Acknowledgments}

We gratefully acknowledge two anonymous reviewers and editors for their helpful and constructive comments on the original manuscript.
This work would not have been possible without the logistical support by two INSU-CNRS observatories run by IPGP: the Observatoire Volcanologique et Sismologique de Guadeloupe and the Observatoire de l'Eau et de l'Erosion aux Antilles. We would like to thank DEAL (especially M. Pellegrinelly-Verdier) for providing hydrological data, and the Parc National de Guadeloupe for field assistance. Thanks are extended to P. Sak and A. White for their help in the field. H. Lazard (LGE) and E. Joigneaux (ISTO) are also thanked for their help on $\mathrm{C}$ and $\mathrm{N}$ analysis and on the $\delta^{13} C_{\text {Doc }}$ analysis, respectively. Financial support was provided by INSU-CNRS (PPF OBSERA). H.L. Buss acknowledges support from an International Scholars Grant from NSF EAR 0725019.

\section{References}

Agren, G.I., Bosatta, E., Balesdent, J., 1996. Isotope discrimination during decomposition of organic matter: a theoretical analysis. Soil Sci. Soc. Am. J. 60, 1121-1126.

Aitkenhead-Peterson, J.A., McDowell, W.H., Neff, J.C., 2003. Sources, production, and regulation of allochthonous dissolved organic matter inputs to surface waters. In: Findlay, S.E.G., Sinsabaugh, R.L. (Eds.), Aquatic Ecosystems: Interactivity of dissolved organic matter. Academic Press, San Diego, USA, pp. 25-70.

Albéric, P., Gautret, P., Juchelka, D., 2010. irm-LC/MS: $\delta^{13} \mathrm{C}$ analysis of dissolved organic matter in natural waters. Thermo Scientific Application Note: 30198, p. 4

Allemand, P., Delacourt, C., Lajeunesse, E., Devauchelle, O., Beauducel, F., 2014. Erosive effects of the storm Helena (1963) on Basse-Terre Island (Guadeloupe-Lesser Antilles Arc). Geomorphology 206, 79-86.

Alvarez-Cobelas, M., Angeler, D.G., Sanchez-Carrillo, S., Almendros, G., 2012. A worldwide view of organic carbon export from catchments. Biogeochemistry 107, 275-293.

Amiotte-Suchet, P., Aubert, D., Probst, J.-L., Gauthier-Lafaye, F., Probst, A., Andreux, F. Viville, D., 1999. $\delta^{13} \mathrm{C}$ pattern of dissolved inorganic carbon in a small granitic catchment: the Strengbach case study (Vosges mountains, France). Chem. Geol. 159 (1-4), $129-145$.

Amiotte-Suchet, P., Linglois, N., Leveque, J., Andreux, F., 2007. ${ }^{13} \mathrm{C}$ composition of dissolved organic carbon in upland forested catchments of the Morvan Mountains (France): influence of coniferous and deciduous vegetation. J. Hydrol. 335 (3-4), 354-363.

Andreux, F., Cerri, C., Vose, P.B., Vitorello, V.A., 1990. Potential of stable isotope, ${ }^{15} \mathrm{~N}$ and ${ }^{13} \mathrm{C}$, methods for determining input and turnover in soils. In: Harrison, A.F. Ineson, P., Heal, O.W. (Eds.), Nutrient Cycling in Terrestrial Ecosystems: Field Methods, Application and Interpretation. Elsevier Applied Science, London, UK, pp. 259-275.

Andrews, J.A., Matamala, R., Westover, K.M., Schlesinger, W.H., 2000. Temperature effects on the diversity of soil heterotrophs and the $\delta^{13} \mathrm{C}$ of soil-respired $\mathrm{CO}_{2}$. Soil Biol Biochem. 32, 699-706.

Balesdent, J., Mariotti, A., 1996. Measurement of soil organic matter turnover using ${ }^{13} \mathrm{C}$ natural abundance. In: Boutton, T.W., Yamashi, S. (Eds.), Mass Spectrometry of Soils. Marcel Dekker, New York, USA, pp. 83-111.

Balesdent, J., Girardin, C., Mariotti, M., 1993. Site-related $\delta^{13} \mathrm{C}$ of tree leaves and soil organic matter in a temperate forest. Ecology 74 (6), 1713-1721.

Bardy, M., 2008. Evolution des matières organiques au cours de la podzolisation des latérites du haut bassin amazonien (Site du Jau, Brésil) (PhD Thesis) Université Pierre et Marie Curie, Paris, France, p. 201.

Bass, A.M., Bird, M.I., Liddell, M.J., Nelson, P.N., 2011. Fluvial dynamics of dissolved and particulate organic carbon during periodic discharge events in a steep tropical rainforest catchment. Limnol. Oceanogr. 56 (6), 2282-2292.

Baudin, F., Tribovillard, N., Trichet, J., 2007. Géologie de la Matière Organique. Société Géologique de France, Vuibert, Paris, France, p. 272.

Bellanger, B., Huon, S., Velasquez, F., Vallès, V., Girardin, C., Mariotti, A., 2004. Monitoring soil organic carbon erosion with $\delta^{13} \mathrm{C}$ and $\delta^{15} \mathrm{~N}$ on experimental field plots in the Venezuelan Andes. Catena 58, 125-150.

Benner, R., 2004. What happens to terrestrial organic matter in the ocean? Mar. Chem. 92 $307-310$.

Blair, N., Leu, A., Muñoz, E., Olsen, J., Kwong, E., Des, Marais D., 1985. Carbon isotopic fractionation in heterotrophic microbial metabolism. Appl. Environ. Microbiol. 50, 996-1001.

Blanchart, E., Bernoux, M., 2005. Déterminants des stocks de carbone des sols des Petites Antilles (Martinique, Guadeloupe). Alternatives de séquestration du carbone et spatialisation des stocks actuels et simulés. Report Progamme GESSOL, IRD. Ministère de l'Ecologie et du Développement Durable, Montpellier, France, p. 104.

Boström, B., Comstedt, D., Ekblad, A., 2007. Isotope fractionation and ${ }^{13} \mathrm{C}$ enrichment in soil profiles during the decomposition of soil organic matter. Oecologia 153, 89-98.

Boutton, T.W., 1996. Stable carbon isotope ratios of soil organic matter and their use as indicators of vegetation and climate change. In: Boutton, T.W., Yamasaki, S. (Eds.), Mass spectrometry of soils, Marcel Dekker. Ink, New York, USA, pp. 47-82.

Buss, H.L., White, A.F., Dessert, C., Gaillardet, J., Blum, A.E., Sak, P.B., 2010. Depth profiles in a tropical volcanic critical zone observatory: Basse-Terre, Guadeloupe. In: TorresAlvarado, I.S., Birkkle, P. (Eds.), Proc. of the 13th Intl. Symp. on Water-Rock Interaction, pp. 245-248.

Cabidoche, Y.M., Achard, R., Cattan, P., Clermont-Dauphin, C., Massat, F., Sansoulet, J., 2009. Long-term pollution by chlordecone of tropical volcanic soils in the French West Indies: a simple leaching model accounts for current residue. Environ. Pollut. 157, 1697-1705. 
Cattan, P., Voltz, M., Cabidoche, Y.-M., Lacas, J.-G., Sansoulet, J., 2007. Spatial and temporal variations in percolation fluxes in a tropical Andosol influenced by banana cropping patterns. J. Hydrol. 355, 157-169.

Chin, Y.-P., Alken, G., O'Loughlin, E., 1994. Molecular weight, polydispersity, and spectroscopic properties of aquatic humic substances. Environ. Sci. Technol. 28, 1853-1858.

Clergue, C., Dellinger, M., Buss, H.L., Gaillardet, J., Benedetti, M.F., Dessert, C., 2015 Influence of atmospheric deposits and secondary minerals on Li isotopes budget in a highly weathered catchment, Guadeloupe (Lesser Antilles). Chem. Geol. 414, $28-41$

Colmet-Daage, F., Bernard, Z., 1979. Contribution à l'Atlas des départements d'Outre-mer: Guadeloupe. Carte des sols de la Guadeloupe, Grande-Terre, Marie-Galante. Carte des pentes et du modelé de la Guadeloupe, Grande-Terre, Marie-Galante. ORSTOM, Antilles.

Colmet-Daage, F., Lagache, P., 1965. Caractéristiques de quelques groupes de sols dérivés de roches volcaniques aux Antilles françaises. Cahiers ORSTOM. Ser. Pédol. 3 (1), 3-20.

Dawson, J.J.C., Soulsby, C., Tetzlaff, D., Hrachowitz, M., Dunn, S.M., Malcolm, I.A., 2008. Influence of hydrology and seasonality on DOC exports from three contrasting upland catchments. Biogeochemistry 90, 93-113.

Deines, P., 1980. The carbon isotope composition of reduced organic carbon. In: Fritz, P., Fontes, J.C. (Eds.), Handbook of Environmental isotope Geochemistry. Elsevier, Amsterdam, pp. 329-406.

Desjardins, T., 1991. Variations de la distribution de la matière organique (carbone total et ${ }^{13} \mathrm{C}$ ) dans les sols ferrallitiques du Brésil. Modifications consécutives à la déforestation et à la mise en culture en Amazonie orientale (PhD thesis) University of Nancy I, p. 144

Desjardins, T., Andreux, F., Volkoff, B., Cerri, C.C., 1994. Organic carbon and ${ }^{13} \mathrm{C}$ contents in soils and soil size-fractions, and their changes due to deforestation and pasture installation in eastern Amazonia. Geoderma 61, 103-118.

Dessert, C., Lajeunesse, E., Lloret, E., Clergue, C., Crispi, O., Gorge, C., Quidelleur, X., 2015 Controls on chemical weathering on a mountainous volcanic tropical island: Guadeloupe (French West Indies). Geochim. Cosmochim. Acta 171, 216-237.

Emanuel, K.A., 2005. Increasing destructiveness of tropical cyclones over the past 30 years. Nature 436, 686-688.

Feuillet, N., Beauducel, F., Tapponnier, P., 2011. Tectonic context of moderate to large historical earthquakes in the Lesser Antilles and mechanical coupling with volcanoes. J. Geophys. Res. 116, B10308.

Finlay, J.C., Kendall, C., 2007. Stable isotope tracing of temporal and spatial variability in organic matter sources to freshwater ecosystems. In: Michener, R., Lajtha, K. (Eds.) Stable isotopes in ecology and environmental science. Blackwell Publishing Ltd, Oxford, UK, pp. 283-333.

Flexor, J.-M., Volkoff, B., 1977. Distribution de l'isotope stable ${ }^{13} \mathrm{C}$ dans la matière organique d'un sol ferrallitique de l'État de Bahia (Brésil). C. R. Acad. Sci. Sér. D 284 (17), 1655-1657.

Fujii, K., Uemura, M., Hayakawa, C., Funakawa, S., Sukartiningsih, Kosaki, T., Ohta, S., 2009 Fluxes of dissolved organic carbon in two tropical forest ecosystems of East Kalimantan, Indonesia. Geoderma 152, 127-136.

Garten Jr., C.T., Cooper, L.W., Post III, W.M., Hanson, P.J., 2000. Climate controls on forest soil C isotope ratios in the Southern Appalachian Mountains. Ecology 81, $1108-1119$.

Gregory, P.J., Ingram, J.S.I., Campbell, B., Goudriaan, J., Hunt, L.A., Landsberg, J.J., Linder, S. Stafford Smith, M., Sutherst, R.W., Valentin, C., 1999. Managed production systems. In: Walker, B., Steffen, W.L., Canadell, J., Ingram, J.S.I. (Eds.), The Terrestrial Biosphere and Global Change. Implications for Natural and Managed EcosystemsSynthesis volume. Cambridge University Press, Cambridge, UK, pp. 229-270.

Hedges, J.I., Keil, R.G., Berner, R., 1997. What happens to terrestrial organic matter in the ocean? Org. Geochem. 27, 195-212.

Henriet, C., Bodarwé, L., Dorel, M., Draye, X., Delvaux, B., 2008. Leaf silicon content in banana (Musa spp.) reveals the weathering stage of volcanic ash soils in Guadeloupe Plant Soil 313, 71-82.

Hilton, R.G., Galy, A., Hovius, N., 2008a. Riverine particulate organic carbon from an active mountain belt: importance of landslides. Glob. Biogeochem. Cycles 22, GB1017.

Hilton, R.G., Galy, A., Hovius, N., Chen, M.C., Horng, M.J., Chen, H., 2008b. Tropical-cyclonedriven erosion of the terrestrial biosphere from mountains. Nat. Geosci. 1, 759-762.

Hope, D., Billett, M.F., Cresser, M.S., 1994. A review of the export of carbon in river water: fluxes and processes. Environ. Pollut. 84, 301-324.

Huang, T.-H., Fu, Y.-H., Pan, P.-Y., Chen, C.-T.A., 2012. Fluvial carbon fluxes in tropical rivers. Curr. Opin. Environ. Sustain. 4, 162-169.

Kaiser, K., Guggenberger, G., Zech, W., 2001. Isotopic fractionation of dissolved organic carbon in shallow forest soils as affected by sorption. Eur. J. Soil Sci. 52 (4), 585-597.

Kauffman, J.H., Sombroek, W.G., Mantel, S., Schulte, A., Ruhiyat, D., 1998. Soils of rainforests: characterization and major constraints of dominant forest soils in the humid tropics. In: Schulte, A., Ruhiyat, D. (Eds.), Soils of Tropical Forest Ecosystems: Characteristics, Ecology and Management. Springer, Berlin, Germany, pp. 9-20.

Kendall, C., Silva, S.R., Kelly, V.J., 2001. Carbon and nitrogen isotopic compositions of particulate organic matter in four large river systems across the United States. Hydrol. Process. 15 (7), 1301-1346

Koutika, L.-S., Bartoli, F., Andreux, F., Cerri, C.C., Burtin, G., Choné, T., Philippy, R., 1997. Organic matter dynamics and aggregation in soils under rain forest and pastures of increasing age in the eastern Amazon Basin. Geoderma 76, 87-112.

Ladyman, S.J., Harkness, D.D., 1980. Carbon isotope measurement as an index of soil development. Radiocarbon 22 (3), 885-891.

Lal, R., 2004. Soil carbon sequestration impacts on global climate change and food security. Science 304, 1623-1627.

Lichtfouse, E., Dou, S., Girardin, C., Grably, M., Balesdent, J., Béhar, F., Vandenbroucke, M. 1995. Unexpected 13C-enrichment of organic carbon components from wheat crop soils: evidence for the in situ origin of soil organic matter. Org. Geochem. 23 (9) 865-868. et, E., Dessert, C., Gaillardet, J., Albéric, P., Crispi, O., Chaduteau, C., Benedetti, M.F., 2011. Comparison of dissolved inorganic and organic carbon yields and fluxes in the watersheds of tropical volcanic islands, examples from Guadeloupe (French West Indies). Chem. Geol. 280, 65-78.

Lloret, E., Dessert, C., Pastor, L., Lajeunesse, E., Crispi, O., Gaillardet, J., Benedetti, M.F., 2013. Dynamic of particulate and dissolved organic carbon in small volcanic mountainous tropical watersheds. Chem. Geol. 351, 229-244.

Ludwig, B., Heil, B., Flessa, H., Beese, F., 2000. Dissolved organic carbon in seepage water-production and transformation during soil passage. Acta Hydrochim. Hydrobiol. 28, 77-82.

Ludwig, W., Amiotte-Suchet, P., Probst, J.L., 1996a. River discharges of carbon to the world's oceans: determining local inputs of alkalinity and of dissolved and particulate organic carbon. C. R. Acad. Sci. II A 323, 1007-1014.

Ludwig, W., Probst, J.L., Kempe, S., 1996b. Predicting the ocean input of organic carbon by continental erosion. Glob. Biogeochem. Cycles 10 (1), 23-41.

Mariotti, A., 1991. Le carbone 13 en abondance naturelle, traceur de la dynamique de la matière organique des sols et de l'évolution des paléoenvironnements continentaux. Cah. ORSTOM Ser. Pedol. 26 (4), 299-313.

Mariotti, A., Balesdent, J., 1990. 13C natural abundance as a tracer of soil organic matter turnover and paleoenvironment dynamics. Chem. Geol. 84, 217-219.

Mulholland, P.J., 2003. Large-scale patterns in dissolved organic carbon concentration. Flux, and sources. In: Findlay, S.E.G., Sinsabaugh, R.L. (Eds.), Aquatic Ecosystems: Interactivity of Dissolved Organic Matter. Academic Press, San Diego, USA, pp. 139-160

Neff, J.C., Asner, G.P., 2001. Dissolved organic carbon in terrestrial ecosystems: synthesis and a model. Ecosystems 4, 29-48.

Ngo, K.M., Turner, B.L., Muller-Landau, H.C., Davies, S.J., Larjavaara, M., Nik Hassan, N.F.B., Lum, S., 2013. Carbon stocks in primary and secondary tropical forests in Singapore. For. Ecol. Manag. 296, 81-89.

Nissenbaum, A., Kaplan, I.R., 1972. Chemical and isotopic evidence for the in situ origin of marine humic substances. Limnol. Oceanogr. 17 (4), 570-582.

van Noordwijk, M., Cerri, C., Woomer, P.L., Nugroho, K., Bernoux, M., 1997. Soil carbon dynamics in the humid tropical forest zone. Geoderma 79, 187-225.

Opfergelt, S., Georg, R.B., Delvaux, B., Cabidoche, Y.M., Burton, K.M., Halliday, A.N., 2012. Mechanisms of magnesium isotope fractionation in volcanic soil weathering sequences, Guadeloupe. Earth Planet. Sci. Lett. 341-344, 176-185.

Peuravuori, J., Pihlaja, K., 1997. Molecular size distribution and spectroscopic properties of aquatic humic substances. Anal. Chim. Acta 337, 133-149.

Plaisir, J., Démonio, W., Claudin, J., 2003. Atlas du Parc National de Guadeloupe. Ministère de l'Ecologie et du Développement Durable, Guadeloupe.

Rivé, K., Gaillardet, J., Agrinier, P., Rad, S., 2013. Carbon isotopes in the rivers from the Lesser Antilles : origin of the carbonic acid consumed by weathering réactions in the Lesser Antilles. Earth Surf. Process. Landf. 38, 1020-1035.

Rousteau, A., 1996. Structures, flores, dynamiques : réponses des forêts pluviales des Petites Antilles aux milieux montagnards. In: Guillaumet, J.L., Belin, M., Puig, H. (Eds.), Phytogéographie Tropicale : Réalités et Perspectives. ORSTOM, Paris, pp. 307-321.

Rousteau, A., Portecop, J., Rollet, B., 1994. Carte écologique de la Guadeloupe. Université Antilles-Guyane, ONF, Conseil Général, Parc National de la Guadeloupe, Guadeloupe.

Sak, P.B., Navarre-Sitchler, A.K., Miller, C.E., Daniel, C.C., Gaillardet, J., Buss, H.L., Lebedeva, M.I., Brantley, S.L., 2010. Controls on rind thickness on basaltic andesite clasts weathering in Guadeloupe. Chem. Geol. 276 (3-4), 129-143.

Samper, A., Quidelleur, X., Komorowski, J.C., Lahitte, P., Boudon, G., 2009. Effusive history of the Grande Découverte Volcanic Complex, southern Basse-Terre (Guadeloupe, French West Indies) from new K-Ar Cassignol-Gillot ages. J. Volcanol. Geotherm. Res. 187 (1-2), 117-130.

Samper, A., Quidelleur, X., Lahitte, P., Mollex, D., 2007. Timing of effusive volcanism and collapse events within an oceanic arc island: Basse-Terre, Guadeloupe archipelago (Lesser Antilles Arc). Earth Planet. Sci. Lett. 258, 175-191.

Schlesinger, W.H., 1977. Carbon balance in terrestrial detritus. Annu. Rev. Ecol. Syst. 8, 51-81. Schlesinger, W.H., Melack, J.M., 1981. Total of organic carbon in the world's rivers. Tellus $33,172-187$.

Schlünz, B., Schneider, R.R., 2000. Transport of terrestrial organic carbon to the oceans by rivers: re-estimating flux- and burial rates. Int. J. Earth Sci. 88, 599-606.

Schulte, A., Ruhiyat, D., 1998. Soils of Tropical Forest Ecosystems. Characteristics, Ecology and Management. Springer-Verlag, Berlin, Deutschland, p. 206.

Schwartz, D., 1993. Les retombées de litière en tant que source du carbone et de l'azote du sol: quantification et périodicité des apports en relation avec les caractéristiques climatiques et édaphiques dans deux parcelles de forêt dense à Dimonika (Mayombe, Congo). In: Cros, B., Diamouangana, J., Kabala, M. (Eds.), Echanges forêt-atmosphère en milieu tropical humide : recueil de travaux effectués dans le Mayombe. UNESCO, Paris, France, pp. 141-158.

Shen, Y.-H., 1999. Sorption of natural dissolved organic matter on soil. Chemosphere 38 (7), 1505-1515.

Snowdon, P., Ryan, P., Raison, J., 2005. Review of C:N ratios in vegetation, litter and soil under Australian native forests and plantations. Issue 45 of National Carbon Accounting System technical report. Australian Greenhouse Office, Department of the Environment and Heritage, Canberra, Australia, p. 60.

Sugimura, Y., Suzuki, Y., 1988. A high-temperature catalytic oxidation method for the determination of non-volatile dissolved organic carbon in seawater by direct injection of a liquid sample. Mar. Chem. 24 (2), 105-131.

Waterloo, M.J., Oliveira, S.M., Drucker, D.P., Nobre, A.D., Cuartas, L.A., Hodnett, M.G., Langedijk, I., Jans, W.W.P., Tomasella, J., de Araujo, A.C., Pimentel, T.P., Munera Estrada, J.C., 2006. Export of organic carbon in run-off from an Amazonian rainforest blackwater catchment. Hydrol. Process. 20, 2581-2597.

Webster, P.J., Holland, G.J., Curry, J.A., Chang, H.-R., 2005. Changes in tropical cyclone number, duration, and intensity in a warming environment. Science 309, 1844-1846. 
Weishar, J.L., Aiken, G.R., Bergamaschi, B.A., Fram, M.S., Fuji, R., Mopper, K., 2003. Evaluspecific ultraviolet absorbance as an indicator of the chemical composition and reactivity of dissolved organic carbon. Environ. Sci. Technol. 37, 4702-4708.

Wohl, E., Barros, A., Brunsell, N., Chappell, N.A., Coe, M., Giambelluca, T., Goldsmith, S., Harmon, R., Hendrickx, J.M.H., Juvik, J., McDonnell, J., Ogden, F., 2012. The hydrology of the humid tropics. Nat. Clim. Chang. 2, 655-662.

Yang, Y.H., Fang, J.Y., Guo, D.L., Ji, C.J., Ma, W.H., 2010. Vertical patterns of soil carbon, nitrogen and carbon: nitrogen stoichiometry in Tibetan grasslands. Biogeosci. Discuss. $7,1-24$.
Zahibo, N., Pelinovsky, E., Talipova, T., Rabinovich, A., Kurkin, A., Nikolkina, I., 2007. Statistical analysis of cyclone hazard for Guadeloupe, Lesser Antilles. Atmos. Res. 84, 13-29. Zsolnay, A., 2003. Dissolved organic matter: artefacts, definitions and functions. Geoderma 113 (3-4), 187-209. 